\title{
Heart rate recovery index in patients with psoriasis
}

\author{
Psoriasisli hastalarda kalp hızı toparlanma indeksi
}

\author{
Serkan Bulur, M.D., Hakan Turan, M.D.," Yusuf Aslantaş, M.D., \\ Zehra Gürlevik, M.D.," Mustafa Özşahin, M.D., ${ }^{\dagger}$ Handan Ankaralı, M.D.,, İsmail Ekinözü, M.D., \\ Sabri Onur Çağlar, M.D., Hakan Özhan, M.D.
}

Departments of Cardiology, "Dermatology, †Physical Medicine and Rehabilitation, ‡Biostatistics, Duzce University Faculty of Medicine, Duzce

\section{ABSTRACT}

Objectives: In clinical practice, autonomic functions are indirectly investigated with heart rate recovery (HRR) index measurements. Our aim was to evaluate the HRR index in patients with psoriasis, which is a systemic inflammatory disease.

Study design: The study population included 39 psoriasis patients (18 female, mean age $48 \pm 15$ years) and 40 control group (18 female, mean age $44 \pm 9$ years) healthy individuals. The severity of psoriasis was calculated using the psoriasis area and severity index (PASI). None of the study patients had a PASI score $>50$. All of the participants underwent treadmill exercise testing using the Bruce protocol.

Results: According to basic clinical and demographic characteristics, both groups were similar with regard to age, body mass index, and fasting glucose and cholesterol levels. No significant differences were observed in the systolic or diastolic blood pressures or resting heart rates between the two groups. All patients and control-group participants had sinus rhythm and normal 12-lead ECG results at rest. All subjects completed the exercise tests to exhaustion without rhythm abnormalities, ischemic changes, or other complications. The maximal heart rate and metabolic equivalents achieved during the exercise stress test (EST) were similar in the psoriasis and control group $(163 \pm 16$ vs. $170 \pm 16$, $p=0.07 ; 9.8 \pm 0.9$ vs. $10.1 \pm 1.0, p=0.24$, respectively). The 1st, 3rd, and 5th minute HRR indices of patients with psoriasis were similar to those of the control group (HRR1: $30 \pm 12$, $32 \pm 18, p=0.71$; HRR3: $57 \pm 13,64 \pm 17, p=0.10$; HRR5: $64 \pm 15,68 \pm 16, p=0.46$, respectively).

Conclusion: The HRR index, which is calculated by an EST and associated with autonomic nervous system function, is not effected in mild to moderate psoriasis patients.

\section{ÖZET}

Amaç: Kardiyak otonomik işlevler klinik uygulamada kalp hızı toparlanma (KHT) indeksi ile dolaylı yoldan ölçülebilir. Bu çalışmada sistemik enflamatuvar bir hastalık olan psoriasisli bireylerde KHT indeksininin araştırılması amaçlandı.

Çalışma planı: Çalışmaya 39 psoriasis hastası (18 kadın, ort. yaş $48 \pm 15$ yıl) ve 40 sağlıklı birey (18 kadın, ort. yaş $44 \pm 9$ yıl) kontrol grubu olarak alındı. Psoriasisin ciddiyeti psoriasis bölge ve ciddiyet indeksine (PASi) göre hesaplandı. Çalışmaya alınan hastaların hiçbirinin PASi skoru >50 değildi. Tüm katılımcılara Bruce protokolü kullanılarak tredmil egzersiz testi uygulandı.

Bulgular: Temel klinik ve demografik özelliklerine göre, her iki grup yaş, beden kütle indeksi, açlık kan şekeri ve kolesterol düzeyleri benzerdi. İki grup arasında sistolik veya diyastolik kan basıncı veya istirahat kalp hızlarında anlamIı bir fark gözlenmedi. Tüm hastalar ve kontrol grubu katıIımcıları sinüs ritmine ve dinlenmede normal 12 derivasyonlu EKG sonucuna sahipti. Tüm katılımcılar ritim anormallikleri, iskemik değişiklikler veya diğer komplikasyonlar olmadan yorgunluk ile egzersiz testini tamamladı. Egzersiz stres testi sırasında maksimal kalp hızı ve metabolik eşdeğere ulaşma psoriasis ve kontrol grubunda benzer bulundu (sırasıyla; $163 \pm 16$ ve $170 \pm 16, p=0.07 ; 9.8 \pm 0.9$ ve $10.1 \pm 1.0$, $\mathrm{p}=0.24)$. Birinci, üçüncü ve beşinci dakikadaki KHT indeksleri psoriasisli hastalar ile kontrol grubunda benzerdi (sırasıyla, KHT1: $30 \pm 12,32 \pm 18, p=0.71$; KHT3: $57 \pm 13,64 \pm 17$, $p=0.10$; KHT5: 64 $\pm 15,68 \pm 16, p=0.46$ ).

Sonuç: Otonomik sinir sisteminin bir göstergesi olan ve egzersiz testi ile ölçülen KHT indeksi hafif orta derece hastalığa sahip psoriasisli bireylerle etkilenmemiştir. 
$\mathrm{P}$ soriasis is a chronic and recurrent inflammatory disease characterized by erythrosquamous plaques, especially on the extensor surfaces of the body and the scalp. ${ }^{[1]}$ It affects approximately $2 \%$ of the population. Psoriasis has been associated with subclinical markers of atherosclerosis, increased allcause mortality, and cardiovascular death. ${ }^{[2]}$ Although the association between psoriasis and cardiovascular disease has been established in hospital-based studies and population-based cohorts, the increase in cardiovascular risk in patients with psoriasis is much higher, particularly in those with severe psoriasis. In addition, their cardiovascular risk is similar to that of diabetic patients. ${ }^{[2]}$ However, cardiovascular risk in patients with mild to moderate psoriasis has not been well established.

Slow heart rate recovery (HRR) has been reported to be important in predicting mortality in patients with heart failure and in healthy individuals. ${ }^{[3,4]}$ Additionally, the exercise stress test (EST), which is used for detecting exercise and functional capacity, can provide useful indirect data about autonomic functions. The chronotropic index and HRR time after an exercise period, which are calculated from the EST data, can reflect chronotropic competence and autonomic functions. HRR is considered to be an indirect reflector of parasympathetic reactivation after an exercise period. ${ }^{[5]}$ Some studies have shown that decreased HRR is associated with high-sensitivity C-reactive protein (hsCRP) levels in elderly individuals and in unselected patients. ${ }^{[6]}$

Autonomic function, such as heart rate variability and heart rate, but not HRR index, was studied in patients with psoriasis. Therefore, we sought to investigate the HRR index in patients with psoriasis.

\section{PATIENTS AND METHODS}

\section{Study population}

The study population included 39 patients (18 female, mean age $48 \pm 15$ years) with psoriasis and 40 healthy individuals (18 female, mean age $44 \pm 9$ years) as the control group. The severity of psoriasis was calculated using the psoriasis area and severity index (PASI). ${ }^{[7]}$ None of the study patients had a PASI score $>50$. Patients with a PASI score between 0.1 and 10.9 were accepted as mild and those having a score between 11 and 49.9 were considered to be moderate. Patients with a body mass index $>30 \mathrm{~kg} / \mathrm{m}^{2}$, and those having diabetes mellitus, hypertension, heart failure, coronary artery disease, renal diseases, or autoimmune disorders were excluded.

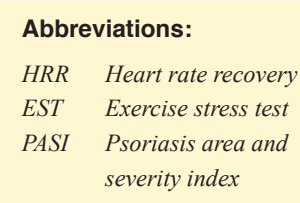

Abbreviations: Psoriasis area and severity index

All of the participants underwent treadmill exercise testing using the Bruce protocol (Nihon-Kohden's Model ECG-9320 K). The predicted peak heart rate was calculated by subtracting the patient's age from 220 , and the aim was to reach at least $85 \%$ of the age-predicted peak heart rates. The HRR index was defined as the reduction in heart rate from the peak exercise to the rate at the $1 \mathrm{st}, 3 \mathrm{rd}$, and 5 th minutes after the cessation of exercise stress test (HRR1, HRR3, and HRR5). The local ethical committee approved the study protocol and all of the patients signed a consent form.

\section{Statistical analysis}

Statistical Package for Social Sciences software (SPSS 12, Chicago, IL, USA) was used for analysis. Sample size was computed by using a power analysis. In this analysis, an effect size of $5 \pm 8$ beat $/ \mathrm{min}$ for HRR was regarded as significant, Type I error and power value were accepted as $5 \%$ and $80 \%$, respectively. The minimum sample size was calculated to be 40 for each group.

Normal distribution of the continuous variables were analyzed using histogram curves, hypothesis tests, skew ness kurtosis, concordance of the mean, median, and standard deviation. Normally distributed continuous variables were compared within two independent groups using an independent samples t-test, and the results were presented as mean \pm standard deviation. Nominal data were compared between two groups using a chi-square test and were presented as frequency and percent (\%). Variables that did not have a normal distribution were compared using a MannWhitney U-test. A $p$ value of $<0.05$ was accepted as significant.

\section{RESULTS}

The baseline characteristics of the study population are shown in Table 1. None of the psoriatic patients had severe disease (a PASI score $>50$ ). According to basic clinical and demographic characteristics, both groups were similar with regard to age, body mass index, and fasting glucose and cholesterol levels. No 
significant differences were observed in the systolic or diastolic blood pressures or resting heart rates between the two groups. The mean duration of disease was $10 \pm 8$ years in the patients with psoriasis. All patients and control-group participants had sinus rhythm and normal 12-lead ECG results at rest. All subjects completed the exercise tests to exhaustion without rhythm abnormalities, ischemic changes, or other complications. The maximal heart rate and metabolic equivalents achieved during the exercise stress test were similar in the psoriasis and control group ( $163 \pm 16$ vs. $170 \pm 16, \mathrm{p}=0.07 ; 9.8 \pm 0.9$ vs. $10.1 \pm 1.0$, $\mathrm{p}=0.24$, respectively).

The HRR index and exercise time of both groups are shown in Table 2. According to these results, the $1 \mathrm{st}, 3 \mathrm{rd}$, and 5th minute HRR index of patients with psoriasis were similar to those of the control group.

\section{DISCUSSION}

In this study, we demonstrated that HRR index is not impaired in the 1st, $3 \mathrm{rd}$, and 5th minutes of the recov- ery period after maximal exercise testing in patients with psoriasis as compared to control subjects. To our knowledge, this is the first study evaluating exercise stress test HRR index in patients with psoriasis.

Numerous studies have demonstrated that patients with severe psoriasis have greater cardiovascular risk than patients with mild-moderate psoriasis. ${ }^{[2]}$ Martyn-Simmons et al ${ }^{[8]}$ assessed endothelial function in patients with psoriasis after excluding traditional risk factors for cardiovascular disease. Jensen et al. ${ }^{[9]}$ showed that endothelial functions in patients with mild-moderate psoriasis are not altered. These studies demonstrated that endothelial functions were not diminished in patients with psoriasis, and that psoriasis is not a cardiovascular risk factor.

Autonomic nervous system abnormalities are seen when sympathetic tone predominates or parasympathetic (vagal) tone diminishes, or when both of these events occur at the same time. When sympathetic activity is greatly amplified, the increased cardiovascular workload and hemodynamic stress can result in

\begin{tabular}{|c|c|c|c|c|c|c|c|}
\hline & \multicolumn{3}{|c|}{$\begin{array}{l}\text { Psoriasis group } \\
\qquad(\mathrm{n}=39)\end{array}$} & \multicolumn{3}{|c|}{$\begin{array}{l}\text { Control group } \\
\qquad(n=40)\end{array}$} & \multirow[t]{2}{*}{$p$} \\
\hline & $\mathrm{n}$ & $\%$ & Mean \pm SD & $\mathrm{n}$ & $\%$ & Mean \pm SD & \\
\hline \multicolumn{8}{|l|}{ Sex } \\
\hline Male & 18 & 46 & & 18 & 45 & & \\
\hline Female & 21 & 54 & & 22 & 55 & & \\
\hline Age (years) & & & $48 \pm 15$ & & & $44 \pm 9$ & 0.17 \\
\hline BMI $\left(\mathrm{kg} / \mathrm{m}^{2}\right)$ & & & $27.1 \pm 3.4$ & & & $26.1 \pm 2.4$ & 0.57 \\
\hline Systolic BP (mmHg) & & & $130 \pm 9$ & & & $126 \pm 11$ & 0.18 \\
\hline Diastolic BP (mmHg) & & & $80 \pm 9$ & & & $79 \pm 8$ & 0.52 \\
\hline Heart rate (beats/min) & & & $80 \pm 12$ & & & $79 \pm 10$ & 0.21 \\
\hline Smoker & 19 & 49 & & 14 & 35 & & 0.35 \\
\hline PASI Score & & & $6.3 \pm 11$ & & & - & - \\
\hline Fasting glucose (mg/dl) & & & $100 \pm 8$ & & & $96 \pm 10$ & 0.66 \\
\hline Total cholesterol (mg/dl) & & & $194 \pm 36$ & & & $188 \pm 27$ & 0.50 \\
\hline LDL-cholesterol (mg/dl) & & & $111 \pm 34$ & & & $109 \pm 23$ & 0.76 \\
\hline HDL-cholesterol (mg/dl) & & & $46 \pm 13$ & & & $47 \pm 11$ & 0.57 \\
\hline Plasma triglyceride $(\mathrm{mg} / \mathrm{dl})$ & & & $150 \pm 58$ & & & $148 \pm 60$ & 0.90 \\
\hline Disease duration (years) & \multicolumn{3}{|c|}{8 (min. 3 - maks. 18) } & & & & \\
\hline hs-CRP & \multicolumn{3}{|c|}{$2.7(\min .1 .2-\max .6 .4)$} & \multicolumn{3}{|c|}{$0.7(\min .0 .2-\max .0 .9)$} & $<0.0001$ \\
\hline
\end{tabular}

BMI: Body mass index; BP: Blood pressure; PASI: Psoriasis area and severity index; hsCRP: High-sensitivity C-reactive protein; LDL: Low-density lipoprotein; HDL: High-density lipoprotein. 
Table 2. 1st, 3rd, and 5th minute heart rate recovery index and total exercise time

\begin{tabular}{lccc}
\hline & Psoriasis group $(n=39)$ & Control group $(n=40)$ & $p$ \\
\hline HRR1 & $30 \pm 12$ & $32 \pm 18$ & 0.71 \\
HRR3 & $57 \pm 13$ & $64 \pm 17$ & 0.10 \\
HRR5 & $64 \pm 15$ & $68 \pm 16$ & 0.46 \\
Exercise time (min) & $9.1 \pm 1.0$ & $9.5 \pm 1.3$ & 0.12 \\
\hline HRR: Heart rate recovery. & & &
\end{tabular}

endothelial dysfunction, coronary artery spasm, left ventricular hypertrophy, serious arrhythmias, stroke, and increased cardiac death. Increased parasympathetic activity is protective against ischemia-related arrhythmias and also reduces heart rate and blood pressure ${ }^{[10]}$ However, in the present study, we found no significant difference in the resting heart rates between patients with mild to moderate psoriasis and the control group.

The autonomic nervous system plays a central role in regulating cardiovascular function. The rise in heart rate during exercise is considered to be due to the activation of the sympathetic nervous system and the simultaneous suppression of the parasympathetic nervous system. ${ }^{[3]}$ On the other hand, the immediate fall in heart rate after exercise is regarded to be a function of parasympathetic reactivation and sympathetic withdrawal. ${ }^{[11]}$ In the literature, HRR has been investigated in various inflammatory diseases such as familial Mediterranean fever, Behçet's disease, and systemic lupus erythematosus. It was shown that the HRR index is impaired in these patients as compared to control subjects. ${ }^{[12-14]}$ Several studies have shown that impaired HRR index after exercise is a powerful independent predictor of cardiovascular and all-cause mortality in healthy individuals. ${ }^{[3,15]}$

It is still unclear whether higher inflammation levels are associated with decreased HRR over time or whether decreased HRR is associated with high levels of inflammatory markers. We demonstrated that there is no significant alteration of HRR in patients with mild to moderate psoriasis, possibly due to the lower grade of inflammation in these patients as compared to their severe psoriatic counterparts. There may be a decrease of HRR in severe psoriasis; however, we could not recruit any severe psoriasis subjects in the present cohort. Therefore, studies with larger cohorts including patients with severe psoriasis are needed.
Heart rate recovery, which is calculated with an exercise stress test and is associated with autonomic nervous system function, remained unchanged in patients with mild-moderate psoriasis. We believe that there is not enough inflammation for autonomic dysfunction in these psoriatic groups. Larger studies are needed in order to determine the effect of disease state on cardiac autonomic dysfunction in patients with severe psoriasis.

\section{Conflict-of-interest issues regarding the authorship or article: None declared}

\section{REFERENCES}

1. Schön MP, Boehncke WH. Psoriasis. N Engl J Med 2005;352:1899-912.

2. Ahlehoff $\mathrm{O}$, Gislason $\mathrm{GH}$, Charlot $\mathrm{M}$, Jørgensen $\mathrm{CH}$, Lindhardsen J, Olesen JB, et al. Psoriasis is associated with clinically significant cardiovascular risk: a Danish nationwide cohort study. J Intern Med 2011;270:147-57.

3. Cole CR, Blackstone EH, Pashkow FJ, Snader CE, Lauer MS. Heart-rate recovery immediately after exercise as a predictor of mortality. N Engl J Med 1999;341(18):1351-7.

4. Cole CR, Lauer MS, Bigger JT. Clinical assessment of the autonomic nervous system. In: Topol EJ, editor.Textbook of cardiovascular medicine. 2nd ed. Philadelphia: Lippincott Williams \& Wilkins; 2002. p. 1615-32.

5. Arena R, Guazzi M, Myers J, Peberdy MA. Prognostic value of heart rate recovery in patients with heart failure. Am Heart J 2006;151:851.e7-13.

6. Chien MY, Lee P, Tsai YF, Yang PC, Wu YT. C-reactive protein and heart rate recovery in middle-aged men with severe obstructive sleep apnea. Sleep Breath 2012;16:629-37.

7. Ramsay B, Lawrence CM. Measurement of involved surface area in patients with psoriasis. Br J Dermatol 1991;124:56570 .

8. Martyn-Simmons CL, Ranawaka RR, Chowienczyk P, Crook MA, Marber MS, Smith $\mathrm{CH}$, A prospective case-controlled cohort study of endothelial function in patients with moderate to severe psoriasis. Br J Dermatol 2011;164:26-32.

9. Jensen PR, Zachariae C, Hansen P, Skov L. Normal endothe- 
lial function in patients with mild-to-moderate psoriasis: a case-control study. Acta Derm Venereol 2011;91:516-20.

10. Curtis BM, O'Keefe JH Jr. Autonomic tone as a cardiovascular risk factor: the dangers of chronic fight or flight. Mayo Clin Proc 2002;77:45-54.

11. Imai K, Sato H, Hori M, Kusuoka H, Ozaki H, Yokoyama H, et al. Vagally mediated heart rate recovery after exercise is accelerated in athletes but blunted in patients with chronic heart failure. J Am Coll Cardiol 1994;24:1529-35.

12. Ardic I, Kaya MG, Yarlioglues M, Dogdu O, Celikbilek M, Akpek M, et al. Assessment of heart rate recovery index in patients with familial Mediterranean fever. Rheumatol Int 2011;31:121-5.

13. Kaya EB, Yorgun H, Akdogan A, Ates AH, Canpolat U, Sunman $\mathrm{H}$, et al. Heart-rate recovery index is impaired in Be- hçet's disease. Tex Heart Inst J 2009;36:282-6.

14. Dogdu O, Yarlioglues M, Kaya MG, Ardic I, Oguzhan N, Akpek M, et al. Deterioration of heart rate recovery index in patients with systemic lupus erythematosus. J Rheumatol 2010;37:2511-5.

15. Nishime EO, Cole CR, Blackstone EH, Pashkow FJ, Lauer MS. Heart rate recovery and treadmill exercise score as predictors of mortality in patients referred for exercise ECG. JAMA 2000;284:1392-8.

Key words: Psoriasis; exercise test; heart rate; heart rate recovery index.

Anahtar sözcükler: Psoriasis; egzersiz testi; kalp hızı; kalp hızı toparlanma indeksi. 